\title{
Penambahan á-tocopherol sebagai Antioksidan pada Pengencer Tris Kuning Telur Spermatozoa Kucing pada Suhu $4^{\circ} \mathrm{C}$
}

\author{
(ADDITION OF Á-TOCOPHEROL AS AN ANTIOXIDANT TO TRIS-EGG YOLK \\ DILUENTS OF CAT SPERMATOZOA AT TEMPERATURE $\left.4^{\circ} \mathrm{C}\right)$
}

\author{
Titis Prastiwi ${ }^{1}$, Wahono Esthi Prasetyaningtyas ${ }^{2 *}$, \\ Ni Wayan Kurniani Karja ${ }^{3}$
}

${ }^{1}$ Mahasiswa Fakultas Kedokteran Hewan, ${ }^{2}$ Departemen Anatomi, Fisiologi dan Farmakologi,

${ }^{3}$ Departemen Klinik Reproduksi dan Patologi,

Fakultas Kedokteran Hewan, Insitut Pertanian Bogor

Jl. Agatis Kampus IPB Dramaga, Bogor, Jawa Barat,Indonesia 16680

*Email: wahono_esti@apps.ipb.ac.id

\begin{abstract}
ABSTRAK
Stres oksidatif memiliki efek merugikan pada kualitas semen selama pengolahan semen untuk inseminasi buatan. Antioksidan á-Tocopherol merupakan salah satu antioksidan yang termasuk ke dalam kelompok antioksigen. Antioksidan ini dapat mengurangi aksi radikal bebas dan menurunkan stress oksidatif pada sperma. Penelitian ini bertujuan menguji efektivitas penambahan á-tocopherol pada pengencer tris-kuning telur terhadap kualitas semen cair yang berasal dari kauda epididimis kucing. Kauda epipidimis kucing didapatkan dengan metode kebiri. Kauda epididimis kemudian dipisah dan dicacah untuk mendapatkan spermatozoa kucing. Semen dengan motilitas $>70 \%$ diencerkan pada kelompok pengencer tris kuning telur (TKT), tris kuning telur dengan á-tocopherol 0,1\% (TKT+T-0,1\%), tris kuning telur dengan á-tocopherol 0,2\% (TKT+T-0,2\%), dan tris kuning telur dengan á-tocopherol 0,3\% (TKT+T0,3\%). Semen cair disimpan selama 4 hari (H0-H4) pada suhu $4^{\circ} \mathrm{C}$, kemudian dilakukan evaluasi kualitasnya (motilitas, viabilitas, abnormalitas dan membran plasma utuh sperma) setiap 24 jam. Hasil penelitian menunjukkan kualitas semen cair tidak berbeda signifikan pada H0 (P>0,05), tetapi penambahan á-tocopherol secara umum meningkatkan kualitas semen pada $\mathrm{H} 4$ pascapreservasi. Berdasarkan hasil penelitian, kelompok pengencer TKT+T-0,1\% adalah perlakuan terbaik.
\end{abstract}

Kata kunci: antioksidan; kucing; tris kuning telur; á-tocopherol; radikal bebas.

\begin{abstract}
Oxidative stress has detrimental effects on semen quality during semen processing for artificial insemination. The á-Tocopherol is an antioxidant that belongs to a group known as antioxygen. These antioxidants can reduce the action of hydrogen peroxide, leading to a decrease in sperm oxidative stress. The aim of the research was to evaluate the post-preservation quality of cat semen (motility, viability, abnormality, and membrane plasma integrity.) Semen collection was carried out by castration method then the cauda epididimis is separated and sliced to get the cat's spermatozoa. Semen with motility $>$ $70 \%$ were grouped and diluted with different extenders; tris-egg yolk extender (TKT), tris-egg yolk extender with á-tocopherol 0,1\% (TKT + T-0,1\%), tris-egg yolk extender with á-tocopherol 0,2\% (TKT+ T-0,2\%), trisegg yolk extender with á-tocopherol $0.3 \%$ (TKT+ T-0,3\%). All semen samples were preserved in $4^{\circ} \mathrm{C}$ for 4 days $(\mathrm{H} 0-\mathrm{H} 4)$. The semen samples were evaluated the parameter of spermatozoa immediately (motility, viability, abnormality, and membranes plasma integrity) every 24 hours. The result showed that there were no significant changes in semen quality on $\mathrm{H} 0(\mathrm{P}>0,05)$. In general, the supplementation of á-tocopherol maintained the semen quality of $\mathrm{H} 4$ post-preservation. Furthermore, the result showed that TKT+T- $0,1 \%$ extender is the best extender and treatment.
\end{abstract}

Keywords: antioxidant; cat; tris-egg yolk; á-tocopherol; free radicals 


\section{PENDAHULUAN}

Kelangsungan hidup suatu spesies penting karena setiap individu mempunyai jangka waktu hidup terbatas dan hanya dengan reproduksi kelangsungan hidup dapat terjaga. Kucing termasuk dalam keluarga Felidae, termasuk di dalamnya spesies kucing besar seperti harimau, macan dan singa. Kucing memiliki tiga jenis genus yaitu; Phantera, Felis dan Acinonyx (Edwards, 2005).

Koleksi material genetik adalah salah satu upaya mengembangbiakan kucing atau hewan lain. Salah satu cara koleksi material genetik pada hewan jantan yang mati adalah koleksi semen yang berasal dari kauda epididimis (Rizal et al., 2004). Semen dari kauda epididimis memungkinkan untuk dilakukan pengolahan dan penyimpanan, karena semen tersebut memiliki kualitas yang sama dengan ejakulat. Axner et al. (1998) menunjukkan bahwa semen dari kauda epididimis telah mengalami pematangan di bagian kaput dan korpus epididimis dan memiliki molititas yang sama seperti semen hasil ejakulasi. Spermatozoa hasil penyimpanan dapat digunakan untuk inseminasi buatan (IB), intra cytoplasmic sperm injection (ICSI), dan in vitro embryo production (IVEP) sehingga memperoleh individu yang baru (Yulnawati et al., 2005).

Penerapan teknologi reproduksi, khususnya IB, menggunakan semen cair atau beku yang diolah dari hasil koleksi semen. Terdapat beberapa metode untuk koleksi semen, di antaranya adalah menggunakan vagina buatan, pemijatan, dan elektroejakulator, metode untuk koleksi spermatozoa bisa juga dilakukan dari kauda epididimis (Zambelli dan Cunto, 2006). Pengolahan semen menentukan kualitas semen yang digunakan untuk IB. Salah satu komponen penting yang menentukan kualitas spermatozoa adalah bahan pengencer. Komponen dalam bahan pengencer harus memenuhi kebutuhan serta fungsi fisiologis spermatozoa sehingga kualitas spermatozoa dapat dipertahankan selama penyimpanan (Wicaksono dan Arifiantini, 2009). Selain itu, bahan pengencer diharapkan tidak bersifat toksik, dan dapat melindungi dari kejutan dingin baik untuk semen beku atau semen cair (Kusumawati dan Leondro, 2011).

Preservasi semen dapat menyebabkan kematian spermatozoa, karena rusaknya membran plasma spermatozoa akibat peroksidasi lipid/lemak. Peroksidasi lemak merupakan proses kompleks yang terjadi karena reaksi polyunsaturated fatty acid atau asam lemak tak jenuh, fosfolipid penyusun membran sel dengan radikal bebas (Rizal et al., 2009). Antioksidan merupakan molekul yang dapat menekan radikal bebas, sehingga mampu mencegah kerusakan spermatozoa dan mempertahankan kualitasnya. Antioksidan yang berasal dari luar (eksogen) dapat membantu mempertahankan kualitas spermatozoa. Salah satu antioksidan yang dapat digunakan adalah á-tocopherol. Antioksidan tersebut bekerja dengan menyumbang ion hidrogen, sehingga mampu mengubah radikal peroksil menjadi radikal tocopherol yang kurang aktif (Wardlaw dan Jeffrey, 2007), peristiwa tersebut mampu menghambat dan menekan efek kerusakan asam lemak/peroksidasi lemak (Vernet et al., 2004). Penambahan á-tocopherol pada pengencer telah digunakan dalam kriopreservasi semen berbagai jenis ternak, yaitu kambing boer (Alawiyah dan Hartono, 2006), sapi (Dasrul et al., 2012), sapi madura (Ratnani et al., 2017) dan ayam pelung (Hendiyani et al., 2018). Sampai saat ini, penelitian tentang penambahan á-tocopherol pada semen cair kucing belum banyak dilaporkan, sehingga penelitian ini bertujuan untuk mengevaluasi pengaruh penambahan átocopherol pada pengenceran semen kucing dengan beberapa konsentrasi berbeda yang dipreservasi pada suhu $4^{\circ} \mathrm{C}$.

\section{METODE PENELITIAN}

\section{Koleksi Semen}

Sebanyak dua puluh lima buah testis digunakan untuk penelitian ini. Testis diperoleh dari klinik hewan di Bogor dari pasien kucing yang dikebiri. Testis yang didapatkan kemudian dibawa ke laboratorium untuk diproses selanjutnya. Testis disimpan dalam $\mathrm{NaCl}$ fisiologis dan dibawa menggunakan coolbox dengan waktu perjalanan sekitar 30-45 menit dari klinik hewan ke laboratorium. Bagian kauda epididimis dipisahkan dan dibersihkan dari bagian tunica dartos dan tunica albuginea. Kemudian dilakukan pembilasan dengan cara menyemprotkan larutan $\mathrm{NaCl}$ fisiologis ke kauda epididimis menggunakan spuit $10 \mathrm{~mL}$ dan jarum berukuran 20G. Selanjutnya, testis dilakukan pencacahan dengan pisau bedah dan ditambahkan larutan PBS sebanyak 3-4 mL. Larutan yang mengandung spermatozoa 
tersebut ditampung dalam tabung falcon ${ }^{\circledR} 15 \mathrm{~mL}$, kemudian disentrifugasi dengan kecepatan 1800 rpm selama 8 menit. Supernatan dibuang dan dilakukan penghitungan konsentrasi spermatozoa menggunakan kamar hitung Neubauer, pengamatan terhadap persentase motilitas, viabilitas, abnormalitas dan membran plasma utuh (MPU) hari ke-0. Spermatozoa epididimis selanjutnya diencerkan dan disimpan pada suhu $4{ }^{\circ} \mathrm{C}$ selama empat hari. Suhu refrigerator diukur setiap hari menggunakan termometer.

\section{Pembuatan Bahan Pengencer}

Bahan pengencer yang digunakan terdiri dari $0,03025 \mathrm{~g} / \mathrm{mL}$ tris (hydroxylmethyl) aminomethane (Merck $\left.{ }^{\circledR}\right)$, sebanyak $0,017 \mathrm{~g} / \mathrm{mL}$ citric acid monohydrate (Merck $\left.{ }^{\circledR}\right), 0,0125 \mathrm{~g} / \mathrm{mL}$ $D$ (-) fructose (Merck $\left.{ }^{\circledR}\right), 500 \mathrm{IU} / \mathrm{mL}$ penicillin- $G$ (Sigma-Aldrich $®$ ), 0, mg/mL streptomycin sulfate $\left(\right.$ Meiji $\left.{ }^{\circledR}\right)$, dan $10 \mathrm{~mL}$ mili-Q water. Pengencer dasar tris ditambahkan kuning telur dengan perbandingan $80: 20$, dan mengandung lipoprotein dan lechitin sebagai pelindung membran spermatozoa terhadap efek cold shock (Tsutsui et al., 2003a). Spermatozoa yang telah diencerkan ditambahkan á-tocopherol (SigmaAldrich $($ ) dengan konsentrasi $0,1 \%, 0,2 \%, 0,3 \%$ dan kontrol kemudian dilakukan pemeriksaan $\mathrm{pH}$ dan mikroskopis.

\section{Evaluasi Kualitas Spermatozoa yang Dievaluasi}

Karakteristik kualitas spermatozoa secara mikroskopis yang dievaluasi meliputi konsentrasi, persentase motilitas, viabilitas, abnormalitas, dan membran plasma utuh (MPU) (Muhammad et al., 2016). Persentase spermatozoa motil adalah persentase spermatozoa yang bergerak progresif (bergerak ke depan). Motilitas spermatozoa dievaluasi secara subjektif pada delapan lapang pandang yang berbeda dengan mikroskop cahaya pembesaran 400 kali (Rasul et al., 2001). Angka yang diberikan berkisar antara 0 dan 100\% dengan skala 5\% (Toelihere, 1993). Persentase spermatozoa hidup adalah persentase spermatozoa yang hidup, sedikitnya 200 spermatozoa dievaluasi dengan pewarnaan eosin-nigrosin menggunakan mikroskop cahaya pembesaran 400 kali (Felipe et al., 2008). Spermatozoa yang hidup ditandai oleh kepala yang bening, sedangkan spermatozoa yang mati ditandai oleh kepala berwarna merah.

Persentase membran plasma utuh (MPU) merupakan presentase spermatozoa yang memiliki membran plasma utuh yang dievaluasi dengan metode hypoosmotic swelling (HOS) test (Jeyendran et al., 1984). Komposisi larutan hipoosmotik terdiri atas: 1,35 g fruktosa $+0,73$ $\mathrm{g}$ natrium sitrat yang dilarutkan dengan akuabidestilata hingga mencapai volume 100 $\mathrm{mL}$. Sebanyak $200 \mathrm{~mL}$ larutan hipoosmotik ditambahkan dengan $20 \mathrm{~mL}$ semen dan dicampur hingga homogen kemudian diinkubasi pada suhu $37^{\circ} \mathrm{C}$ selama 45 menit. Preparat ulas tipis dibuat pada gelas objek kemudian dievaluasi dengan bantuan mikroskop cahaya pembesaran 400 kali, terhadap minimum 200 spermatozoa. Spermatozoa yang memiliki membran plasma utuh ditandai oleh ekor melingkar atau menggelembung, sedangkan yang rusak ditandai oleh ekor lurus karena tidak mampu menahan cairan yang masuk ke dalam sel (Ariswan et al., 2014)

\section{Prosedur Analisis Data}

Data motilitas, viabilitas, abnormalitas dan MPU spermatozoa diperoleh dari lima kali pengulangan, dianalisis dengan menggunakan uji sidik ragam satu arah/one-way analysis of variance (ANOVA). Data tersebut kemudian dilanjutkan dengan uji Duncan dengan selang kepercayaan 95\%. Uji Duncan dilakukan jika hasil uji menunjukkan perbedaan yang signifikan antar perlakuan $(\mathrm{P}<0,05)$. Analisis data dilakukan dengan menggunakan program Statistical Package for the Social Sciences (SPSS) 25.

\section{HASIL DAN PEMBAHASAN}

\section{Evaluasi Spermatozoa Sebelum Pengen- ceran}

Hasil pengamatan spermatozoa yang berasal dari kauda epididimis disajikan dalam Tabel 1. Tingkat kepadatan spermatozoa di kauda epididimis masih tinggi, hal ini karena belum adanya penambahan plasma semen dari kelenjar aksesoris. Rataan konsentrasi spermatozoa kucing sebesar $147,5 \pm 54,83$ juta sel/mL setelah sentrifugasi, sebelum sentrifugasi kosentrasi spermatozoa sebesar $61,9 \pm 7,3$ juta sel $/ \mathrm{mL}$. Konsentrasi spermatozoa sebelum disentrifugasi sama dengan laporan Tsutsui et al. (2003b) yang menyatakan bahwa konsentrasi spermatozoa di kauda epididimis sebesar 58-64 juta sel/mL. Hasil ini juga berbeda dengan hasil yang dilaporkan oleh Yulnawati et $A l$. (2005) yang menyatakan bahwa konsentrasi spermatozoa 
Tabel 1. Pemeriksaan mikroskopis spermatozoa kauda epididimis kucing

\begin{tabular}{lc}
\hline Paramater Pengamatan & Hasil \\
\hline Sebelum Sentrifugasi & \\
Motilitas (\%) & $74,5 \pm 0,9$ \\
Viabilitas (\%) & $79,7 \pm 1,9$ \\
Abnormalitas (\%) & $9,6 \pm 1,7$ \\
Membran Plasma Utuh (\%) & $77,7 \pm 1,8$ \\
Konsentrasi spermatozoa & $61,9 \pm 7,3$ \\
(juta sel/mL) & \\
Setelah sentrifugasi & $74,5 \pm 0,9$ \\
Motilitas (\%) & $143,7 \pm 33,6$ \\
Konsentrasi spermatozoa & \\
(juta sel/mL) & \\
\hline
\end{tabular}

Keterangan: data disajikan dalam bentuk rerata dengan standar deviasi $(\mathrm{x} \pm \mathrm{SD})$.

dari kauda epididimis kucing sebesar 108,00 \pm 81,49 juta $\mathrm{sel} / \mathrm{mL}$. Perbedaan konsentrasi diduga akibat adanya perbedaan teknik koleksi spermatozoa, umur, dan nutrisi dari hewan tersebut (Yulnawati dan Setiadi, 2005).

Viabilitas spermatozoa diamati dengan menggunakan pewarnaan eosin nigrosin (Felipe et al., 2008). Spermatozoa hidup ditunjukkan dengan kepala yang bening, sedangkan spermatozoa mati dinilai dari kepala yang bewarna merah jambu/pink (Gambar 1). Hal tersebut karena membran kepala spermatozoa yang sudah mati tidak stabil sehingga mudah menyerap warna eosin nigrosin (Bansal dan Bilaspuri, 2008). Faktor utama yang digunakan untuk menentukan kualitas spermatozoa layak untuk dibekukan adalah viabilitas, pada penelitian ini viabilitas sebesar $79,7 \pm$ $1,9 \%$.

Hasil pengamatan integritas membran plasma utuh (MPU) disajikan pada Gambar 2. Persentase MPU yang diperoleh sebesar 73,90 $\pm 1,10 \%$. Spermatozoa dalam larutan hipoosmotik akan bereaksi karena larutan masuk ke dalam sel melewati membran plasma. Akibat perbedaan tekanan osmotik dari larutan tersebut dengan tekanan osmotik luar sel yang lebih rendah, sehingga larutan tersebut masuk ke dalam sel dan menyebabkan pembengkakan. Kejadian ini dapat diamati pada ekor spermatozoa yang mengalami invaginasi/melingkar. Spermatozoa dengan kerusakan fungsi membran tidak mengalami pembengkakan dan ekornya tidak mengalami invaginasi/melingkar (Jeyendran et al., 1984).
Persentase motilitas spermatozoa epididimis kucing pada penelitian ini sebesar 72,00 $\pm 0,94 \%$, sedangkan abnormalitas spermatozoa (Gambar 3) yang ditemukan dalam penelitian ini sebesar $9,6 \pm 1,7 \%$. Kualitas spermatozoa kauda epididimis kucing menunjukkan hasil yang baik dan memenuhi syarat untuk diproses lebih lanjut dalam bentuk semen cair. Syarat semen yang bisa diolah lebih lanjut antara lain memiliki presentase motilitas e" $70 \%$, abnormal 6-10\%, dan presentase MPU e"60\% (Rizal, 2009).

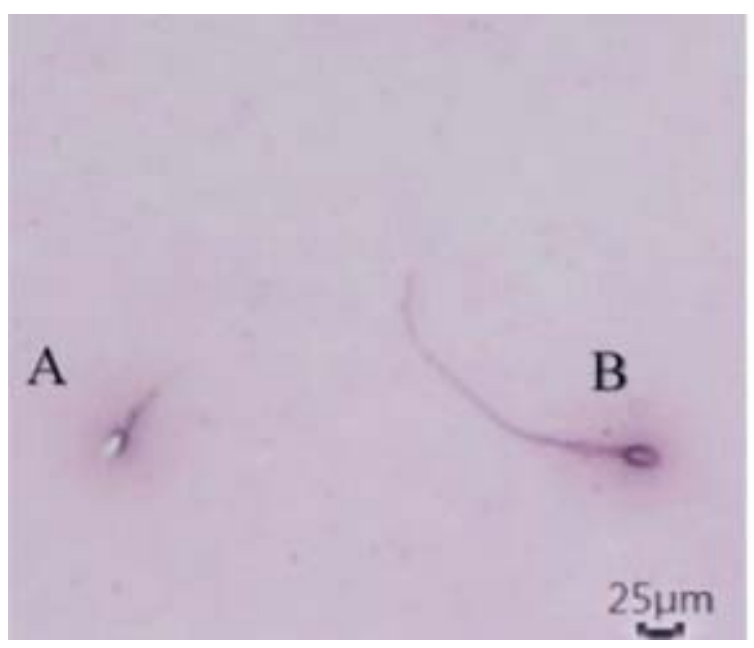

Gambar 1. Viabilitas spermatozoa kauda epididimis kucing; hidup (A), mati (B)

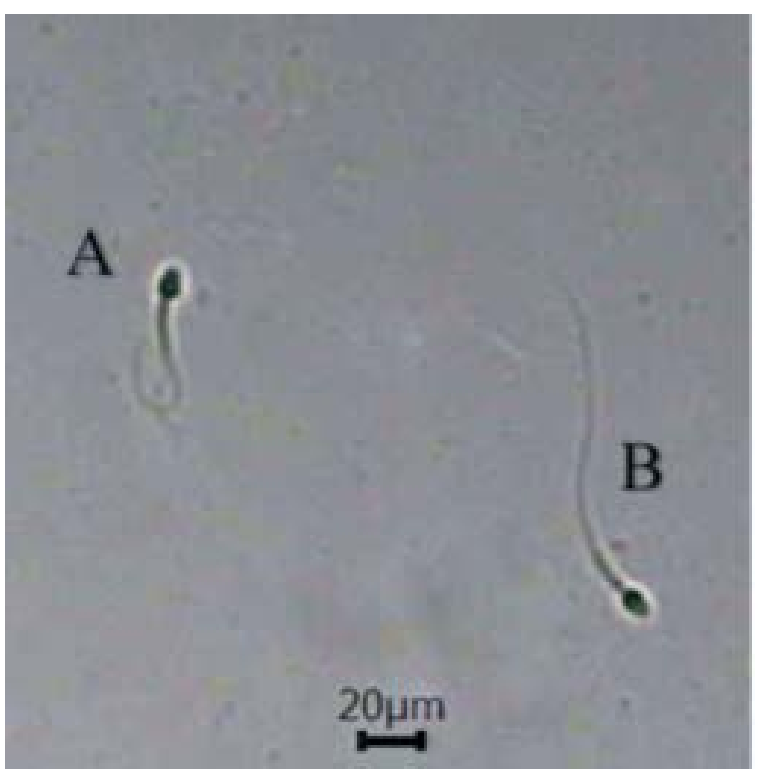

Gambar 2. Membran plasma utuh (MPU) kauda epididimis kucing; membran plasma utuh (A), membran plasma tidak utuh (B) 
Kualitas spermatozoa dievaluasi setiap hari. Evaluasi menunjukkan kualitas spermatozoa yang menurun karena penyimpanan. Parameter motilitas spermatozoa disajikan pada Tabel 2. Motilitas spermatozoa menurun secara signifikan mulai hari ke-1 sampai hari ke-4 penyimpanan $(\mathrm{P}<0,05)$ pada kelompok perlakuan T-0,1\%, T- $0,2 \%$ dan T-0,3\%, sedangkan pada T0 terjadi penurunan yang signifikan mulai hari ke-3 hingga hari ke-4. Penurunan ini kemungkinan diakibatkan adanya penumpukan asam laktat sisa metabolisme sel. Penumpukan asam laktat mengakibatkan turunnya $\mathrm{pH}$ medium (pengencer) menjadi asam, dan dapat menjadi racun terhadap spermatozoa yang mengakibatkan kematian spermatozoa (Sugiarti et al., 2004).

Viabilitas spermatozoa pada kelompok T$0 \%, \mathrm{~T}-0,1 \%, \mathrm{~T}-0,2 \%$, dan T-0,3\% menurun secara signifikan $(\mathrm{P}<0,05)$. Pada H0 tidak menunjukkan perbedaan yang nyata pada setiap kelompok perlakuan $(\mathrm{P}>0,05)$. Viabilitas spermatozoa setelah penyimpanan selama empat hari menunjukkan kelompok T-0,1\% tertinggi dan kelompok T-0,3\% memiliki nilai viabilias terendah. Kelompok T-0\% dan T-0,2 tidak menunjukkan perbedaan yang nyata. Paramater viabilitas digunakan sebagai kemampuan spermatozoa untuk bertahan hidup. Persentase spermatozoa hidup lebih tinggi daripada persentase motilitas. Hal tersebut karena spermatozoa yang hidup belum tentu motil, tetapi jumlah spermatozoa yang tidak motil terkadang masih hidup (Campbell et al., 2003). Penurunan persentase viabilitas juga dapat diakibatkan oleh pengaruh cold shock (Pereiera et al., 2010).

Membran plasma utuh (MPU) spermatozoa kauda epididimis kucing dengan pengencer tris kuning telur yang ditambah á-tocopherol selama empat hari pada suhu $4 \mathrm{p}$ C disajikan pada Tabel 4. Membran plasma utuh sper-

Tabel 2. Motilitas spermatozoa kauda epididimis kucing dengan pengencer tris kuning telur yang ditambah á-tocopherol selama 4 hari pada suhu $4^{\circ} \mathrm{C}$

\begin{tabular}{lccccc}
\hline \multirow{2}{*}{ Pengencer } & \multicolumn{5}{c}{ Motilitas spermatozoa (\% \pm SD) } \\
\cline { 2 - 6 } & H0 & H1 & H2 & H3 & H4 \\
\hline T-0 & $72,00 \pm 0,9 \mathrm{a}$ & $67,20 \pm 2,1 \mathrm{aAB}$ & $61,40 \pm 1,0 \mathrm{aA}$ & $54,00 \pm 1,9 \mathrm{bA}$ & $42,60 \pm 1,9 \mathrm{cA}$ \\
T-0.1\% & $73,00 \pm 0,4 \mathrm{a}$ & $69,40 \pm 1,2 \mathrm{bB}$ & $65,00 \pm 0,6 \mathrm{cB}$ & $60,40 \pm 1,0 \mathrm{~dB}$ & $51,40 \pm 1,9 \mathrm{eB}$ \\
T- $0.2 \%$ & $71,20 \pm 0,7 \mathrm{a}$ & $65,20 \pm 0,8 \mathrm{bA}$ & $58,40 \pm 1,4 \mathrm{cA}$ & $51,90 \pm 1,8 \mathrm{dA}$ & $45,40 \pm 1,6 \mathrm{eA}$ \\
T- $0.3 \%$ & $70,80 \pm 0,5 \mathrm{a}$ & $60,80 \pm 0,5 \mathrm{bC}$ & $53,40 \pm 1,1 \mathrm{cC}$ & $42,70 \pm 1,7 \mathrm{dC}$ & $33,00 \pm 1,2 \mathrm{eC}$ \\
\hline
\end{tabular}

Keterangan: Huruf kecil (a, b, c, d, e) yang berbeda pada baris yang sama dan huruf besar berbeda (A, B, C) pada kolom yang sama menunjukkan perbedaan yang nyata $(\mathrm{P}<0.05)$; H0: evaluasi segera semen diencerkan; H1: evaluasi hari ke-1, H2: evaluasi hari ke-2, H3: evaluasi hari ke-3, H4: evaluasi hari ke-4.

Tabel 3. Viabilitas spermatozoa kauda epididimis kucing dengan pengencer tris kuning telur yang ditambah á-tocopherol selama empat hari pada suhu $4^{\circ} \mathrm{C}$

\begin{tabular}{lccccc}
\hline \multirow{2}{*}{ Pengencer } & \multicolumn{5}{c}{ Viabilitas spermatozoa $(\% \pm \mathrm{SD})$} \\
\cline { 2 - 6 } & H0 & H1 & H2 & H3 & H4 \\
\hline T-0 & $78,42 \pm 1,5 \mathrm{a}$ & $75,92 \pm 1,1 \mathrm{aA}$ & $70,51 \pm 1,2 \mathrm{aAB}$ & $66,90 \pm 1,6 \mathrm{bAB}$ & $60,31 \pm 3,0 \mathrm{cA}$ \\
T-0.1\% & $79,65 \pm 0,9 \mathrm{a}$ & $78,54 \pm 0,7 \mathrm{aA}$ & $72,41 \pm 1,7 \mathrm{bA}$ & $71,12 \pm 2,2 \mathrm{bB}$ & $68,04 \pm 2,3 \mathrm{bB}$ \\
T-0.2\% & $76,45 \pm 1,2 \mathrm{a}$ & $71,26 \pm 1,5 \mathrm{bB}$ & $66,66 \pm 0,7 \mathrm{cBC}$ & $63,89 \pm 1,2 \mathrm{cdA}$ & $61,23 \pm 2,0 \mathrm{dA}$ \\
T-0.3\% & $76,41 \pm 1,3 \mathrm{a}$ & $67,01 \pm 1,7 \mathrm{bC}$ & $62,76 \pm 1,8 \mathrm{bcC}$ & $58,62 \pm 1,5 \mathrm{cC}$ & $53,11 \pm 1,5 \mathrm{dC}$ \\
\hline
\end{tabular}

Keterangan : Huruf kecil (a, b, c, d, e) yang berbeda pada baris yang sama dan huruf besar berbeda (A, B, C) pada kolom yang sama menunjukkan perbedaan yang nyata $(\mathrm{P}<0.05)$; H0: evaluasi segera semen diencerkan; H1: evaluasi hari ke-1, H2: evaluasi hari ke-2, H3: evaluasi hari ke-3, H4: evaluasi hari ke-4. 
matozoa pada semua kelompok menurun secara signifikan mulai hari ke-1 sampai hari ke-4 penyimpanan $(\mathrm{P}<0,05)$. Berdasarkan hasil penelitian terdapat perbedaan yang nyata pada kelompok T-0\% dan T-0,1\% serta T-0,2\% dan T0,3\% selama penyimpanan dari $\mathrm{H} 0$ hingga $\mathrm{H} 4$ $(\mathrm{P}<0,05)$. Kemudian pada hari terakhir penyimpanan keutuhan membran plasma tertinggi yaitu terdapat pada kelompok T-0,1 dan terendah pada kelompok T-0,3. Penyimpanan selama empat hari dapat menyebabkan terjadinya peroksidasi lipid yang akan menyebabkan kerusakan struktur membran plasma terganggu (Suyadi et al., 2015), sehingga nilai MPU naik setelah empat hari penyimpanan.

Penggunaan bahan pengencer tris kuning telur berfungsi sebagai penyangga (buffer) bagi pengencer, sehingga perubahan $\mathrm{pH}$ akibat asam laktat dari hasil metabolisme spermatozoa dapat ditekan. Asam laktat merupakan produk sisa respirasi sel secara anaerob. Pengencer tris kuning telur selain sebagai buffer juga
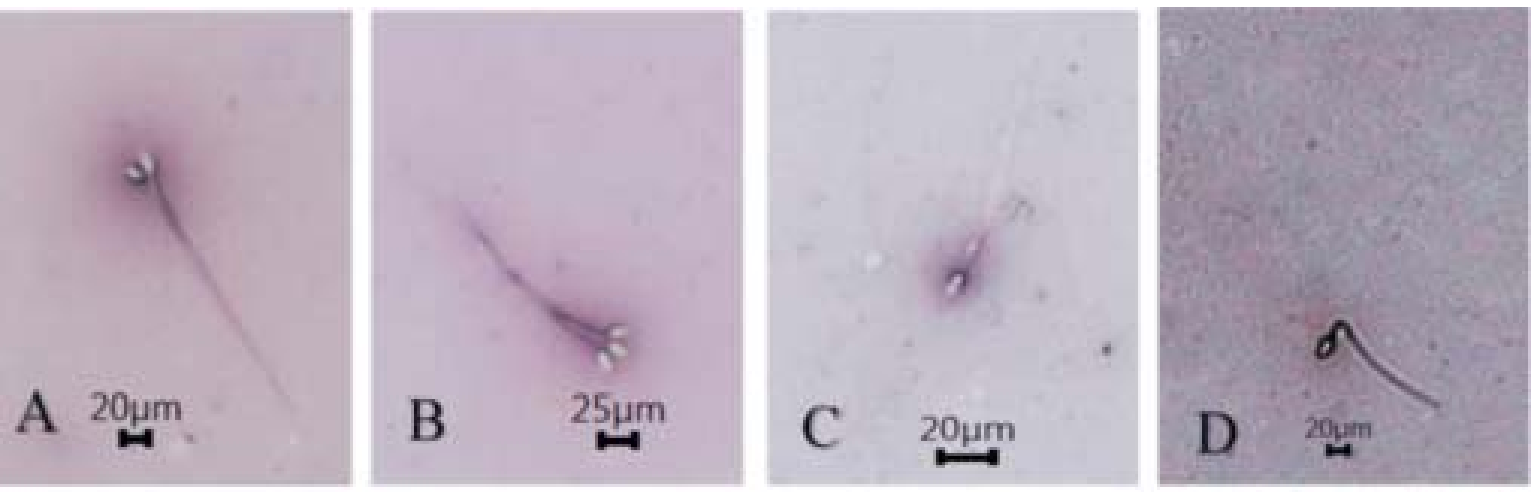

Gambar 3. Abnormalitas spermatozoa kauda epididimis kucing; dichephalic (A) trichephalic (B), Cytoplasmic droplet (C), dan ekor bengkok (D)

Tabel 4. Membran plasma utuh spermatozoa kauda epididimis kucing dengan pengencer tris kuning telur yang ditambah á-tocopherol selama empat hari pada suhu $4^{\circ} \mathrm{C}$

\begin{tabular}{|c|c|c|c|c|c|}
\hline \multirow{2}{*}{ Pengencer } & \multicolumn{5}{|c|}{ Keutuhan membran plasma spermatozoa $(\% \pm \mathrm{SD})$} \\
\hline & Ho & $\mathrm{H} 1$ & $\mathrm{H} 2$ & H3 & $\mathrm{H} 4$ \\
\hline $\mathrm{T}-0$ & $73,90 \pm 1,1 \mathrm{aA}$ & $71,61 \pm 0,9 \mathrm{abA}$ & $67,22 \pm 0,7 \mathrm{abA}$ & $64,70 \pm 0,5 \mathrm{bcAB}$ & $59,04 \pm 2,2 \mathrm{cA}$ \\
\hline $\mathrm{T}-0.1 \%$ & $73,62 \pm 0,9 \mathrm{aAB}$ & $72,20 \pm 0,7 \mathrm{bA}$ & $66,96 \pm 1,0 \mathrm{bcA}$ & $66,19 \pm 1,3 \mathrm{cdA}$ & $64,34 \pm 1,2 \mathrm{~dB}$ \\
\hline $\mathrm{T}-0.2 \%$ & $68,67 \pm 2,7 \mathrm{aB}$ & $66,43 \pm 1,7 \mathrm{abB}$ & $62,51 \pm 0,8 \mathrm{abB}$ & $62,00 \pm 0,7 \mathrm{bcBC}$ & $59,07 \pm 1,1 \mathrm{cA}$ \\
\hline T- $0.3 \%$ & $66,76 \pm 1,5 \mathrm{aB}$ & $63,85 \pm 1,7 \mathrm{bB}$ & $61,89 \pm 1,4 \mathrm{bB}$ & $60,73 \pm 1,0 \mathrm{bcC}$ & $54,50 \pm 1,2 \mathrm{cC}$ \\
\hline
\end{tabular}

Catatan: Huruf kecil (a, b, c, d, e) yang berbeda pada baris yang sama dan huruf besar berbeda (A, B, C) pada kolom yang sama menunjukkan perbedaan yang nyata $(\mathrm{P}<0.05)$; H0: evaluasi segera semen diencerkan; H1: evaluasi hari ke-1, H2: evaluasi hari ke-2, H3: evaluasi hari ke-3, H4: evaluasi hari ke-4. 
spermatozoa. Selanjutnya akan menginaktivasi enzim glikolitik, pemutusan rantai DNA dan menyebabkan kematian spermatozoa. Selain itu ROS dapat menyebabkan mutasi pada DNA mitokondria, bahkan dapat merusak mitokondria sehingga menginduksi terjadinya nekrosis spermatozoa (Dutta et al., 2019). Produksi ROS yang semakin tinggi menyebabkan tingkat peroksidasi lipid pada membran menjadi meningkat (Suryohudoyo, 2000).

Berdasarkan hasil penelitian penambahan á-tocopherol dalam pengencer tris kuning telur pada konsentrasi $0,1 \%$ memberikan hasil terbaik dalam mempertahankan motilitas, viabilitas, dan MPU, sedangkan konsentrasi $0,3 \%$ memberikan hasil terendah. Hasil ini menunjukkan bahwa penambahan á-tocopherol dalam pengencer semen berpengaruh terhadap kualitas spermatozoa kauda epididimis kucing. Menurut Comb (1992) á-tocopherol mempunyai fungsi yang penting untuk memelihara integritas membran pada seluruh sel tubuh. Antioksidan á-tocopherol bertindak sebagai pemutus berbagai reaksi rantai ROS karena kemampuannya untuk memindahkan hydrogen fenolat kepada radikal bebas peroksil dari asam lemak tak jenuh ganda yang telah mengalami peroksidasi (Mayes, 1995).

Penambahan á-tocopherol 0,1\% merupakan dosis optimum di dalam pengencer kuning telur, sehingga dapat mempertahankan kualitas spermatozoa. Keadaan tersebut diduga karena penambahan á-tocopherol menyebabkan optimalisasi laju fruktolisis sehingga kebutuhan energi untuk motilitas dapat terpenuhi. Selain itu, á-tocopherol diduga mampu mengikat oksigen reaktif yang terdapat dalam sel sehingga dapat mencegah terbentuknya peroksidasi lipid yang dapat menghambat glikolisis dan motilitas spermatozoa (Dasrul et al., 2012). Antioksidan á-tocopherol mampu menangkap senyawa oksigen reaktif (ROS) pada pengencer. Menurut Bansal dan Bilaspuri (2008) antioksidan átocopherol bereaksi dengan menyumbangkan satu atom hidrogen dari gugus $\mathrm{OH}$ ke senyawa radikal bebas yang memiliki elektron tidak berpasangan, sehingga menyebabkan terbentuknya radikal tokoferoksil yang bersifat tidak merusak dan stabil, sehingga dapat menghentikan tahap proses propagasi berantai. Kejadian peroksidasi lipid dapat menyebabkan rusaknya membran plasma (Dasrul et al., 2012). Kerusakan membran plasma spermatozoa dapat menurunkan fluiditas membran yang berfungsi sebagai sarana transportasi substrat sumber energi seperti fruktosa masuk ke sel untuk dimetabolisir (fruktolisis) menjadi energi dalam bentuk ATP yang digunakan untuk pergerakan spermatozoa. Energi dalam bentuk ATP akan menurun sehingga motilitas menurun bahkan dapat menimbulkan kematian spermatozoa. Penambahan á-tocopherol dapat mempertahankan dan melindungi membran sel dari serangan senyawa oksigen reaktif. Antioksidan á-tocopherol juga berfungsi sebagai antioksidan intraseluller yang paling kuat, dalam mengurangi atau mencegah peroksidasi lipid tak jenuh di dalam dan pada dinding sel (Suryohudoyo, 2000). Keberadaan antioksidan di dalam pengencer akan meningkatkan kualitas spermatozoa selama preservasi (Ghallab et al., 2017).

Konsentrasi á-tocopherol yang semakin meningkat juga menyebabkan á-tocopherol beralih fungsi sebagai pro-oksidan bukan antioksidan (Tariq et al., 2015). Hal tersebut

Tabel 5. Abnormalitas spermatozoa kauda epididimis kucing dengan pengencer tris kuning telur yang ditambah á-tocopherol selama empat hari pada suhu $4^{\circ} \mathrm{C}$

\begin{tabular}{lrrccc}
\hline & \multicolumn{5}{c}{ Abnormalitas spermatozoa (\% \pm SD) } \\
\cline { 2 - 6 } Pengencer & \multicolumn{1}{c}{ H0 } & H1 & H2 & H3 & H4 \\
\hline T-0 & $10,00 \pm 0,6 \mathrm{a}$ & $11,54 \pm 1,2 \mathrm{abA}$ & $12,30 \pm 1,2 \mathrm{abA}$ & $13,32 \pm 0,9 \mathrm{bcA}$ & $15,10 \pm 1,0 \mathrm{cA}$ \\
T-0.1\% & $8,93 \pm 0,6 \mathrm{a}$ & $11,81 \pm 0,5 \mathrm{bAB}$ & $12,68 \pm 0,4 \mathrm{bcA}$ & $13,84 \pm 0,6 \mathrm{cdA}$ & $15,34 \pm 0,6 \mathrm{dAB}$ \\
T-0.2\% & $10,45 \pm 0,8 \mathrm{a}$ & $12,50 \pm 0,4 \mathrm{bAB}$ & $13,50 \pm 0,4 \mathrm{bAB}$ & $14,97 \pm 0,3 \mathrm{cAB}$ & $17,10 \pm 0,3 \mathrm{dBC}$ \\
T-0.3\% & $11,40 \pm 1,3 \mathrm{a}$ & $13,86 \pm 0,4 \mathrm{abB}$ & $14,88 \pm 0,1 \mathrm{abB}$ & $15,90 \pm 0,2 \mathrm{bcB}$ & $17,46 \pm 0,2 \mathrm{cC}$ \\
\hline
\end{tabular}

Catatan: Huruf kecil (a, b, c, d, e) yang berbeda pada baris yang sama dan huruf besar berbeda (A, B, C) pada kolom yang sama menunjukkan perbedaan yang nyata $(\mathrm{P}<0.05)$; H0: evaluasi segera semen diencerkan; H1: evaluasi hari ke-1, H2: evaluasi hari ke-2, H3: evaluasi hari ke-3, H4: evaluasi hari ke- 4 . 
diakibatkan oleh produksi radikal bebas yang meningkat ataupun produk antioksidan rendah, sehingga menyebabkan keseimbangan yang mengarah pada prooksidan yang dapat meningkatkan stres oksidatif. Dampak dari stres oksidatif yaitu dapat menurunkan kualitas sperma, penurunan motilitas spermatozoa dan meningkatkan jumlah spermatozoa mati (Hendiyani et al., 2018). Selain itu, penambahan á-tocopherol pada konsentrasi tinggi menyebabkan konsentrasi pengencer semakin pekat dan pengencer menjadi hipertonik. Kondisi ini menyebabkan metabolisme spermatozoa menjadi terhambat dan mengakibatkan spermatozoa kehilangan energi. Kondisi kehilangan energi diawali dengan berkurangnya produksi energi untuk bergerak sehingga motilitas spermatozoa menurun dan apabila kondisi tersebut terjadi secara terus menerus dapat menyebabkan kematian spermatozoa (Hartono, 2008).

Persentase abnormalitas spermatozoa kauda epididimis kucing dengan pengencer tris kuning telur yang ditambah á-tocopherol selama penyimpanan empat hari pada suhu $4 \mathrm{p}$ $\mathrm{C}$ disajikan pada Tabel 5. Abnormalitas pada kelompok T-0\%, T-0,1\%, T-0,2\%, dan T-0,3\% meningkat secara signifikan dari hari ke-1 sampai hari ke-4 penyimpanan $(\mathrm{P}<0,05)$. Penyimpanan pada H0 tidak menunjukkan perbedaan yang nyata pada setiap kelompok perlakuan $(\mathrm{P}>0,05)$. Berdasarkan hasil penyimpanan nilai abnormalitas terendah atau yang memiliki jumlah spermatozoa normal paling tinggi terdapat pada kelompok perlakuan kontrol. Abnormalitas dapat terjadi selama proses spermatogenesis, selama perjalanan spermatozoa di epididymis, atau dalam proses preservasi (Parkinson, 2004). Beberapa spermatozoa memiliki abnormalitas pada kepala dan ekor, antara lain trichephalic sedangkan kelainan pada ekor yaitu adanya ekor bengkok dan cytoplasmic droplet (Gambar 3). Secara normal spermatozoa asal kauda epididymis sering ditemukan abnormalitas cytoplasmic droplet (Kauster et al., 2004). Peningkatan jumlah abnormalitas cytoplasmic droplet selama preservasi disebabakan oleh suhu yang dingin (Mekasha et al., 2007). Berdasarkan hasil penelitian tidak terdapat perbedaan yang signifikan pada setiap kelompok pemberian á-tocopherol. Hartono (2008) menyatakan bahwa penambahan antioksidan dalam pengencer tidak memengaruhi persentase abnomalitas spermatozoa.

\section{SIMPULAN}

Penambahan á-tocopherol $0,1 \%$ dalam pengencer tris kuning telur setelah penyimpanan pada suhu $4^{\circ} \mathrm{C}$ selama empat hari, merupakan kelompok perlakuan terbaik dalam mempertahankan motilitas, viabilitas dan membran plasma utuh spermatozoa kucing yang dikoleksi dari kauda epididimis pada penyimpanan suhu $4^{\circ} \mathrm{C}$.

\section{SARAN}

Perlu dilakukan pengujian lebih lanjut mengenai efektivitas penambahan á-tocopherol pada pengencer semen cair terhadap keberhasilan program IB.

\section{UCAPAN TERIMAKASIH}

Penulis mengucapkan terimakasih kepada Laboratorium Bedah Departemen Klinik, Reproduksi, dan Patologi FKH IPB, yang membantu menyediakan epididymis dan testis kucing hasil kebiri yang digunakan untuk penelitian ini.

\section{DAFTAR PUSTAKA}

Alawiyah D, Hartono M. 2006. Pengaruh penambahan vitamin $\mathrm{E}$ pada pengencer sitrat kuning telur terhadap kualitas semen pada kambing Boer. Journal of the Indonesian Tropical Animal Agriculture 31(1): 8-14.

Alvarez JG, Storey. 1995. Differential incorporation of fatty acid into and peroxidative loss of fatty acid from phospholipid of human spermatozoa. Molecular Reproduction and Development 42: 334-345

Ariswan, Saili T, Baa LO, Rahadi S. 2014. Membran plasma utuh sprmatozoa epididimis kambing perranakan ettawa dalam natrium klorida dengan konsentrasi berbeda. Jurnal Ilmu dan Teknologi Peternakan Tropis 1(1): 79-87.

Axner E, Strom B, Linde FC. 1998. Morphologhy of spermatozoa in the cauda epididymis before and after electroejaculation twice 
during the same period of anesthesia. Therogenology 50: 973-979.

Bansal AK, Bilaspuri GS. 2008. Effect of manganese on bovine sperm motility, viability and lipid peroxidation in vitro. Journal of Animal Reproduction 5(3): 90 96.

Campbell JR, Campbell KL, Kanealy MD. 2003. Artificial insemination. In: Animal Science. $4^{\text {th }}$ (Ed). New York (USA). Edward Arnold Publisher Ltd. Hlm. 431.

Combs GF Jr. 1992. The vitamins fundamental aspects in nutrition and health. California (USA). Academic Press Inc. Hlm. 66.

Dasrul, Rasmamaidar, Harris A. 2012. Efektivitas penambahan vitamin E (átocopherol) dalam medium pencucian sperma dengan sentrifugasi terhadap kualitas spermatozoa Sapi Brahma. Agripet. 12(2): 7-13

Dutta S, Majzoub A, Asgarwal A. 2019. Oxidative stress and sperm function: A systematic review on evaluation and management. Arab Journal of Urology 17(2): 87-97.

Edwards. 2005. Cat breeds and cat cares. London (UK). Hermes Home. Hlm. 90-94

Felipe YE, Juarez M, Hermandez G, Velancia. 2008. Viability of fresh and frozen bull sperm compred by staining techniques. Acta Veterinaria Brasilica 2: 123-130.

Ghallab ARM, Abdallah MS, Aya MF, Ayoub MM, Adel RM. 2017. Impact of supp lementation of semen extender with antioxidants on the quality of chilled or cryopreserved Arabian stallion spermatozoa. Cryobiology 79: 14-20.

Hartono M. 2008. Optimalisasi penambahan vitamin $\mathrm{E}$ dalam pengencer sitrat kuning telur untuk mempertahankan kualitas semen kambing Boer. Journal of the Indonesian Tropical Animal Agriculture 33(1): 11-19.

Hendiyani M, Bebas W, Budiasa MK. 2018. Penambahan alfa tocopherol dalam pengenceran terhadap motilitas dan daya hidup spermatozoa ayam pelung pada suhu 4 p C. Medicus Veterinus Indonesia 7(2): 168-176.
Jeyendran RS, Van der Ven HH, Perez PM, Crabo BG, Zenevald LJ. 1984. Devolepment of an assay to assess the functional integrity of the human sperm membrane and its relationship to other semen characteristics. Journal Reproduction Fertile. 70: 219-228.

Kauster CE, Hess RA, Althouse GC. 2004. Immunofluorescence reveals ubiquitination of retained distal cytoplasmic droplets on ejaculated porcine spermatozoa. Journal of Andrology 25: 340-347.

Kusumawati ED, Leondro. 2011. Kualitas semen segar sapi pejantan pada penyimpanan dan lama simpan yang berbeda. Jurnal Sains Veteriner 15(1): 433-439.

Mayes PA. 1995. Struktur dan fungsi vitamin yang larut dalam lemak. Jakarta (ID): Buku Kedokteran EGC. Hlm. 620

Mekasha Y, Tegegne A, Rodrigues M. 2007. Sperm morphology attributes in indigenous male goat raised under extensive husbandry in Euthopia. Animal Reproduction 4: 1522 .

Muhammad D, Susilawati T, Wahjuningsih. 2016. Pengaruh penggunaan CEP-2 dengan suplementasi kuning telur terhadap kualitas spermatozoa sapi FH (Frisian Holstein) kualitas rendah selama penyimpanan suhu 4-5 p C. Jurnal Ternak Tropika 17(1): 66-76.

Parkinson TJ. 2004. Review: Evaluation of fertilitation in infertility in natural service bulls. The Veterinary Journal 168: 215-229.

Pereira GR, Siqueira B, Ferreira R, Severo CK, Truzzi VS, Oliveira JEC, G o n c a lve s PBD. 2010. Assesment of bovine spermatozoa viability using different cooling protocols prior to cryopreservation. Indonesian Journal of Agricultural Science 9(4): 234-237.

Rasul A, Ahmad N, Anzar M. 2001. Changes in motion characteristics, plasma membrane integrity and acrosome morphology during cryopreservation of buffalo spermatozoa. Journal of Andrology 22: 278-283.

Ratnani H, Ihsan MN, Ciptadi G, Sayudi S. 2017. Effect of á-tocopherol supplementation in the extender on the sperm quality of Maduran bull before anda after quick freezing. International Journal of Advanced Research 3(7): 1378-1389. 
Rizal M, Toelihere MR, Yusuf TL, Purwantara B, Situmorang PZ. 2004. Pengaruh waktu penyimpanan epididimis pada suhu $5^{\circ} \mathrm{C}$ terhadap kualitas spermatozoa epididimis domba garut. Jurnal Veteriner 5(3): 95-103.

Rizal M. 2009. Daya hidup spermatozoa epidididmis sapi bali yang dipreservasi pada suhu 3-5 p C dalam pengencer tris dngan konsentrasi laktosa yang berbeda. Jurnal Ilmu Ternak dan Veteriner 14(2): 142-149.

Sugiarti TE, Triwulaninningsih, Situmorang P, Sianturi, Kusumaningrum DA. 2004. Penggunaan katalase dalam Produksi Semen Sapi. Prosiding Seminar Nasional Teknologi peternakan dan Veteriner. Bogor 4-5 Agustus 2004. . Puslitbang Peternakan.

Suryohudoyo. 2000. Ilmu Kedokteran Molekuler. Jakarta. CV Sagung Seto. Hlm. 31-47.

Suyadi TE, Susilorini, Amalta L. 2015. Kualitas semen kambing peranakan etawah dalam pengencer tris terhadap kualitas semen kambing peranakan etawah. Jurnal Ilmu Ternak dan Veteriner 3(4): 22-24.

Tariq M, Khan MS, Shah MG, Nisha AR, Umer M, Hasan SM, Rahman A, Rabbani I. 2015. Exogenous antioxidans inclusion during seme cryopreservation of farm animals. Journal of Chemical and Pharmaceutical Research 7(3): 2273-2280.

Toelihere, M.R. 1993. Inseminasi Buatan pada Ternak. Bandung. Angkasa. Hlm. 146-149

Tsutsui T, Wada M, Anza M, Hori T. 2003a. Artificial insemination with frozen epididymal sperm in cats. The Journal of Veterinary Medical Science 65 (3): 397-399.
Tsutsui T, Mikasa Y, Sugiwawa H, Kirihara N, Hori T, Kawakami E. 2003b. Artificial insemination with canine semen stored at a low temperature. The Journal of Veterinary Medical Science 65(3): 307-312.

Vernet P, Aitken RJ, Drewer JR. 2004. Antioxidant strategies in the epidymidis. Molecular and Cellular Endocrinology 216(1-2): 31-39.

Wardlaw GM, Jeffrey SH. 2007. Perspectives in nutrition. 7th edition. New York (USA). Mc Graw Hill Companies Inc. Hlm. 318-320

Widjaya N. 2011. Pengaruh pemberian susu skim dengan pengencer tris kuning telur terhadap daya tahan hidup spermatozoa sapi pada suhu penyimanan 5 p C. Jurnal Sain Peternakaan Indonesia 9(2): 72-76.

Wicaksono A, Arifiantini RI. 2009. Uji banding empat bahan pengencer untuk preservasi semen anjing retriever. Jurnal Ilmu Ternak dan Veteriner 14: 50-57.

Yulnawati, Setiadi MA. 2005. Motilitas dan keutuhan mempran plasma spermatozoa epididimis kucing selama penyimpanan pada suhu 4 p C. Majalah Kedokteran Hewan 21(3): 100-101.

Yulnawati, Setiadi MA, Herdis. 2005. Pemanfaatan sari buah melon dan sari wortel sebagai media pengencer alternatif semen cair domba Garut. Majalah Kedokteran Hewan 12: 151-160.

Zambelli D, Cunto M. 2006. Semen collection in cats: techniques and analysis. Theriogenology 66: 159-165. 